The Dismantling of the Good Neighbor Policy 
THIS PAGE INTENTIONALLY LEFT BLANK 


\section{The Dismantling of the Good Neighbor Policy}

by Bryce Wood

$\checkmark \sqrt{ }$ University of Texas Press, Austin 
Copyright (C) I 985 by the University of Texas Press All rights reserved

Printed in the United States of America

First Edition, I985

Requests for permission to reproduce material from this work should be sent to Permissions, University of Texas Press, Box 7819, Austin, Texas 787 I3.

\section{Library of Congress Cataloging in Publication Data}

Wood, Bryce, I909-

The dismantling of the good neighbor policy.

Bibliography: $\mathrm{p}$.

Includes index.

I. Latin America-Foreign relations-United States.

2. United States-Foreign relations-Latin America.

I. Title.

FI4I8.W682 I985 327.7308 84-20950

ISBN 0-292-7I I 44-I

ISBN 978-0-292-76649-5 (library e-book)

ISBN 978-0-292-78554-0 (individual e-book) 